\title{
The influence of socio-cultural factors on the performance of female entrepreneurs
}

\author{
Gogo Rachael Adiza ${ }^{1}$, Ule Prince Alamina ${ }^{2 *}$, Idemudia Sunday Aliyu ${ }^{3}$ \\ Department of Office and Information Management, Faculty of Management Sciences, Niger Delta \\ University, Nigeria ${ }^{1}$ \\ Doctoral Scholars, Department of Management, Faculty of Management Sciences, Niger Delta \\ University, Wilberforce Island, Nigeria ${ }^{2,3}$
}

ule.alamina@gmail.com

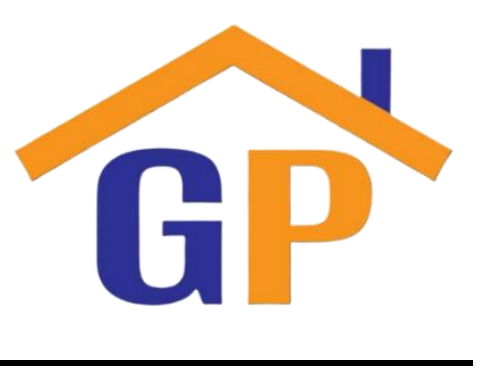

Article History

Received on 14 February 2020

$1^{\text {st }}$ Revision on 17 February 2020

$2^{\text {nd }}$ Revision on 15 March 2020

$3^{\text {rd }}$ Revision on 31 May 2020

Accepted on 15 June 2020

\begin{abstract}
Purpose: The potential contribution of female entrepreneurial activities geared towards the growth and development of economies cannot be neglected despite the numerous challenges faced by women as a result of cultural practices. The study investigated the influence of socio-cultural factors on the performance of female entrepreneurs.
\end{abstract}

Research methodology: A cross sectional survey design was utilized to obtain 160 female entrepreneurs from four Niger Delta States. Data collected using convenience sampling techniques and analyzed with multiple regression.

Result: The outcome revealed that socio-cultural dimensions influenced female entrepreneurial performance at varying degrees hence; it was concluded that since individuals do not live in a vacuum but social context, there is the tendency of cultural factors influencing their behaviours towards business venturing which is the burning desires to gain self recognition and social mobility.

Limitations: The greatest challenge was the researchers' inability to cover the nine Niger Delta States.

Contribution: The study advocated for women education which would equip them with the requisite knowledge to challenge some of the cultural excesses in the region as most men still live in the past by bringing obsolete ideas that infuses negative attitude towards female entrepreneurial engagement in the region.

Keywords: Attitude towards risk-taking, Attitude towards wealth gains, Attitude towards innovation, Push and pull motivations

How to cite: Adiza, G. R., Alamina, U. P., Aliyu, I. S. (2020). The influence of socio-cultural factors on the performance of female entrepreneurs. International Journal of Financial, Accounting, and Management, 2(1), 13-27.

\section{Introduction}

The adventure of women entrepreneurial involvement into new business development has demonstrated significant impact on economic and social development of many nations in the globe. Women innovative ideas on how best to own and run their business enterprises has created indelible mark in history as statistics have proven that female entrepreneurial engagement in micro and small scale enterprises has contributed to nation's economic sustainability in terms of creating jobs and reducing unemployment as well as poverty reduction (Mbiti, Mukulu, Mung'atu \& Kyalo, 2015; Spevacek, 2010). The contemporary burning desire for recognition and social mobility among the female folk in societies has triggered entrepreneurial spirit as a means of improving economic and social status as against opportunity identification. Wilson, Kickul and Marlino (2007) opines that feminine involvement in entrepreneurial ventures are purely for social motives while masculine involvement focuses more on economic goals than social aspect in their entrepreneurial ventures. 
However, the significant role and contributions women play in societal development through entrepreneurial activities cannot be ruled out of place, considering their supportive role to charitable organizations as against their male counterpart (National Foundation for Women Business Owners, 2000; Korosec \& Berman, 2006; Van Ryzin, Grossman, Dipadova-Stocks \& Bergrud, 2009).

Women are proven to be key drivers of viable economic growth globally. This is evidence(d) as research conducted on their potential impact on SMEs economic and social development indicates significant contributions to national and local economies globally. In the United States (US) for instance, the National Women Business Council 2004 provide evidence showing businesses owned by women dominate with about 6.7 million firms growing rapidly and as well adding jobs more than three times faster than the national average. In developing economies like Nigeria, necessity and lack of employment option rather than opportunity identification has been identified as major propellant of women entrepreneurial engagement. Women in this part of the world delves into business activities for the sake of sustenance and household responsibilities and as such choose the type of income generating activities that are less viable on the value chain and easy to manage from home. Incidentally, this has contributed to poor remuneration for female entrepreneurial activities. Some scholars in developing economies have attributed these outcomes to the influence of socio-cultural factors (Kabote, 2018; Adim, Tamunomiebi, Akintokunbo \& Adubasim, 2018), others to attitudinal behaviours towards entrepreneurial activities in term of risk-taking, fear due to lack of confidence and exposure, etc (Tuyishime, Jaya \& Gaurav, 2015; Mauchi, Mutengezanwa \& Damiyano, 2014).

Rahma and Farhana (2014) believe that "social systems and culture grossly affect the development of entrepreneurial spirit and motivation by showing evidence of values that either improve or inhibit entrepreneurship behaviour and drive". Mbiti, et al., (2015) supported these positions but deviate a little to say culture has great impact on attitude and behaviour of individuals and their disposition to life. These disposition and value orientation depends on the person, if he/she can develop and become an entrepreneur or not. On the contrary, Nwibere, Emecheta and Worlu (2011) came up with a view centered on entrepreneurial behaviour which they tie to risk-taking and change, resulting from poor quality of education, attitude towards the use of modern technology, unskilled manpower, etc.

Despite the aforementioned, Aldrich and Zimmer (1986) have long pin point the relevance of sociocultural variables in the decision to create new businesses, arguing that entrepreneurship is embedded in a social context: therefore, women in this cultural niche need to play second fiddle to succeed in their quest to own enterprises. However, the dearth of empirical evidence to support the influence of socio-cultural factors on the performance of female entrepreneurs in the Nigerian context necessitated this study and in achieving this objective, the question to whether or not women engage in entrepreneurial activities as a result of opportunity identification or propelled by necessity and the potential influence cultural factors play on female entrepreneurial engagement is the contention this paper seeks to empirically address.

\section{Literature review and hypothesis development}

\section{Socio-Cultural Factors}

Every society and or organization is made up of people who originate from different cultural background and these cultures affects their attitude, values, abilities, philosophies and performances in one way or the other (Nwibere, et al., 2011) and since individuals do not exist in a vacuum but social context, the tendency of their attitude being influenced by societal norms is pivotal; That is to say no entrepreneur can survive without an understanding of the environment upon which he/she operates. The socio-cultural factor which constitutes the structure of society plays vital role in the practice of entrepreneurs (Ule, 2012). These factors either affect or influence the behaviour of people, their values, belief systems, general attitude to work and their roles in organization. That is why Anikpo and Atemie (2006) argued that culture is indispensable in the study of human social relationship due to its relevance on economic behaviour and entrepreneurship but since society is endowed with different physical environment by nature, entrepreneurs must adopt environmentally relevant patterns of behaviour to achieve success (Shane, 1993). These patterns of behaviour lead to different cultural values, some of which influences the decision to create new venture. However, culture and social systems both affect the development of entrepreneurial spirit and motivation by 
exhibiting values that either improve or reduce entrepreneurship drive and behaviour among individuals (Rahma \& Farhana, 2014). Considering the positions above, the study came up with a conceptual model in order to ascertain the influence of socio-cultural factors on female entrepreneurial performance.

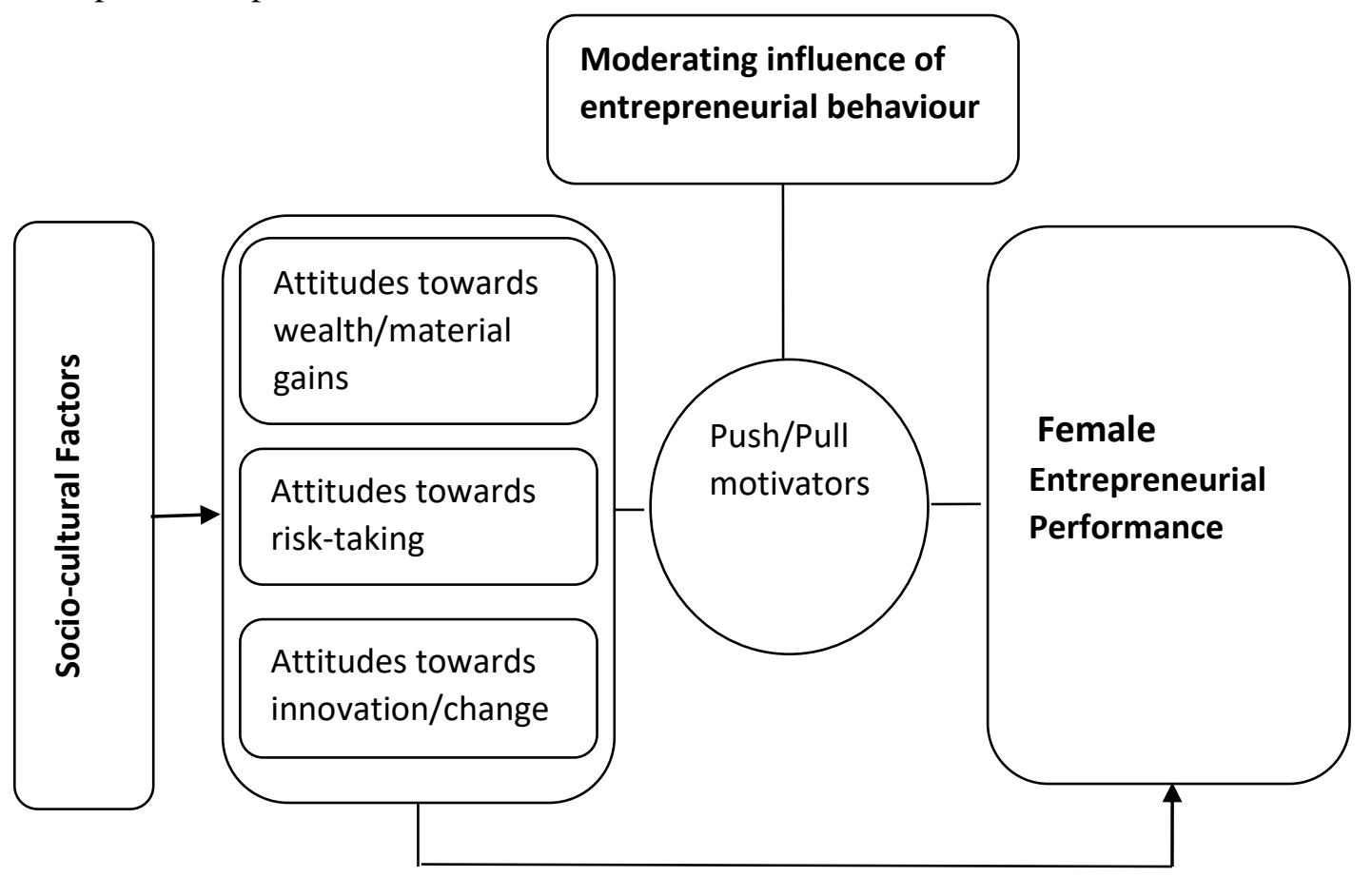

Source: Researcher's Conceptualization, 2019.

Attitude towards wealth and material gains

The dominant views on attitude towards wealth and material gains influences how enterprises are managed thereby having direct bearing on the performance of female entrepreneurs and in order to enhance productivity of scarce resources, individuals maximizes the creation of wealth which is essential for survival. As succinctly posited by Ashley, Nathan and Dunn (2016) wealth creation confers a sense of responsibility to give back to society which enhances satisfaction, yet individuals think of wealth and material gains as a means of achieving social status or contribution to society (Srivastava, Locke \& Bartol, 2001) which in turn instigate entrepreneurs to dedicate effort towards achieving financial success. Entrepreneurs in this context need to develop attitude towards wealth achievement as it is feasible to pursue entrepreneurial career when individuals have high and positive drive for achievement. The need for achievement refers to individual's desire for relevant accomplishment, attainment of goals and mastering skill (Sari, William \& Xu, 2017). Given these predispositions, we hypothesize;

Ho1: There is no significant influence on attitude towards wealth/material gains and female entrepreneurial performance.

\section{Attitude towards risk taking}

The business environment is incredibly risky especially for entrepreneurs seeking high growth opportunity. These individuals on daily bases operates in circles of uncertainty confronted with choices that can influence the future into unanticipated directions (Cocioc, 2017). Risks is the possibility of something bad or good happening at sometime in the future; a situation that could be dangerous or have bad result but despite this, entrepreneurs who venture into risks taking for themselves work harder towards the success they stand to pursue. Our argument here is that female entrepreneurs should be prepared to develop positive attitude towards risks taking despite the challenging cultural factors hovering around the environment as pro-activeness in risks taking aid in lunching new venture thereby enabling entrepreneurs to realize their potentials in life. 
However, female entrepreneurs need to understand the degree of risks taking despite the uncertain knowledge about future occurrence as it could impact positively on their attitude towards the likelihood to starting a venture. According to Shane and Venkataraman (2000) the starting of a business requires the entrepreneur to recognize the opportunity, prepare and exploit the opportunity for greater advantage. These can only be attainable if entrepreneurs adjust their behaviours and attitudes towards preparing themselves for the exploitation of opportunity identified. Based on this we hypothesize the following:

$\mathbf{H o}_{2}$ : There is no significant influence on attitude towards risks taking and female entrepreneurial performance.

\section{Attitude towards change and innovation}

Change and innovation are basic constants every entrepreneur needs to keep at the back of his/her mind. It is a movement from the known to the unknown that affects the behaviour of individuals which in turn affect entrepreneurs' ability to attain set goals. Entrepreneurs' attitude towards change and innovation deals with the extent to which people in society accept cultural changes aimed at improving performance and or productivity. Oshi, Ule and Ogah (2017) opines that the process of creating new ideas feasible to improve goods and services is one that require constant innovative practice, if organizations want to sustain competitive advantage.

The implication in this scholarly argument is that entrepreneurs could only perform at optimum when they are innovative as it would enable them take proactive approach to change in order to avoid potential future threat or capitalize on potential future opportunity. Female entrepreneurs in this cultural context need to make solemn effort to accepting risks involved in doing something new when they are dissatisfied with their current cultural situations. To this end, we came up with the following hypothetical statement;

Ho3: There is no significant influence on attitude towards change/innovation and women entrepreneurial performance.

\section{Propellant of entrepreneurial behaviour}

With the increasing trend of unemployment and mass poverty ravaging underdeveloped nations' of the world, there is a gradual shift of attention to business ventures(ing) with the intent of survival as most individuals in these cultural setting delve into entrepreneurial activities not because of opportunity identification but rather necessity. Despite being an engine for economic growth and wealth creation, entrepreneurial activities tends to be a means of survival to most persons in developing economies. Although scholars have long argue that entrepreneurs engage in entrepreneurial activity due to different motivational factors (Ingrid, Roy, Jolanda \& Peter, 2010) and some scholars attribute these factors to drivers of necessity and drivers of opportunity ( Levine, 1986; Shapero \& Sokol, 1982).

The drivers of necessity (Push or negative) motivations tend to instigate individuals into venture creation for the sake of survival and in most cases exist were there are no better alternative or options. For instance in most Nigerian settings, women engage in entrepreneurial activities not because of opportunity identification and wealth generation but rather necessity to survive the family due to some husband's inability or total negligence of their responsibility to cater for the immediate family thereby pushing these mothers' into all manner of entrepreneurial behaviour in order to survive the circle. Conversely, drivers of opportunity (Pull or positive) motivations are factors that drive individuals into recognizing a business opportunity and pursuing it for personal gains. These categories of entrepreneurs take advantage of every business opportunity to create wealth for themselves and families thereby becoming more successful as a result of their maximization of the available opportunities than the necessity entrepreneurs. Based on these the following null hypotheses are stated below:

Ho4: There is no significant influence between push motivations and female entrepreneurial engagement. 
Hos: There is no significant influence between pull motivations and female entrepreneurial engagement.

\section{Socio-cultural factors and female entrepreneurial involvement}

There is no denying the fact that culture shapes and moderate the behaviour of people in society and its environs but to an extent, the influence of women entrepreneurial engagement in business activities depend on their level of evaluating the business opportunities and initiative put in place to achieve success. Despite Mufaro, Lucky and Noel (2018) position on women entrepreneurial operations involving considerable amount of risks requiring hard work, patience, sincerity of purpose and enormous sacrifices cutting across various challenges, women need to embrace strong entrepreneurial culture since the desire to develop and become an entrepreneur depend on the individual's disposition and value orientation (Mbiti, et al., 2015). These value orientation are key to what instigate entrepreneurs to pursue innovations, wealth and material gains and risk taking propensity even when it is agreed that socio-cultural factors shape and influences the personality of entrepreneurs as well affecting their disposition, behaviour, decisions, attitude and activities (Rahma \& Farhana, 2014) within a given business environment.

Although the fact still remains that, the higher entrepreneur's level of post-materialism in a country, the more individuals consider the wellbeing of others (Hartog \& Hoogendoom, 2011). The dominant view here is that cultures where people have grater aspirations for material gains always instigate desires to achieve but the reverse creates an atmosphere where people take poverty to predestination and consequently demonstrate no absolute interest in wealth acquisition, poverty is expected to reign supreme when this reverse happens.

All over the globe, it is acknowledged that entrepreneurs are risk takers and innovators such that they embark on calculated risks in order to acquire wealth through innovation and venturing. Innovations, venturing and creativity should be part of entrepreneurial value orientation considering the hostile nature of contemporary business environment. Whether pull or push motivational factors, individuals need the willingness to commit relevant resources into opportunities as well creating new or improve goods and services in order to be productive and courageous to face obstacles (Oshi, et al., 2017) leading to survival amidst turbulence.

\section{Performance of female entrepreneurs in Nigeria}

The potential contribution of female entrepreneurial activities to the growth and development of economies cannot be ruled out of place despite the numerous challenges befalling them as a result of cultural practices. Female entrepreneurial engagement has been proven to be viable contributors of economic growth, poverty reduction, unemployment eradication and societal development (Eniola \& Dada, 2018; Urbano, Ferri \& Noguera, 2014) but unfortunately these entrepreneurs operates in an unfavorable environment in the Nigerian context (Adim, et al., 2018). However, despite receiving increasing attention among societies, female entrepreneurs still faces several challenges in their various sectors ranging from weak institutions, infrastructural deficiency, lack of access to proper funding, socio-cultural factors, negative attitude towards business, etc resulting from poor education, mentoring deficiency, rudiment skill, inadequacy of relevant experience among others (Adim, et al., 2018).

Therefore, the need to develop women capabilities in order to stimulate better performance becomes cardinal for female entrepreneurs to achieve their set objectives (Singh \& Manish, 2013). Nevertheless, female entrepreneurial performance becomes relevant in Nigeria to understanding their contribution to national development. Performance is the accomplishment of a given task measured against present known standard of accuracy, completeness and speed. And as a critical element in business venturing, entrepreneurs should develop competencies in a manner that will align with their business goals since the prospect of female entrepreneurs is promising in the Nigerian environment despite the inhibiting cultural influences. 


\section{Research methodology}

The research nature gave rise to positivist philosophical perspective as it involves the use of questionnaires to elicit information from female entrepreneurs. The essence of this philosophical position stem from the fact that female entrepreneurs' attitude are beyond the researchers' control owing to the wide range of data collection. The study adopts Khare (2014) materialism scale for attitude towards wealth/material gains which focused on the maximization of wealth creation as a means of achieving social status, recognition and financial success. Lebedeva and Tatarko (2009) state self-assessment scale of innovative personality traits for attitude towards risk taking and attitude towards innovation/change as modified by this study sort to build in aggressive confident with clear thinking to manipulate business opportunities with the mindset towards creating positive change that comes with creative ideas within the business domain which is fundamental to entrepreneurship and the individual work performance scale of Ramdani, Marliani and Rahman (2019) for female entrepreneurial performance. The various scales as adopted were modified to suit the study meanwhile all the items were ranked on a 5 point likert scale while the moderator (push and pull) items were raised by the researchers. A sample population of one hundred and sixty (160) female entrepreneurs drawn from four (4) States using convenience sampling technique as a result of cost implication in assessing all the female entrepreneurs in the country. The regression statistical technique is used to test the extent of influence as represented in the conceptual model shown above. Below is a table showing the types of female entrepreneurial engagement.

Table 1. Types of female entrepreneurial business involvement

\begin{tabular}{|l|l|l|l|}
\hline S/No & $\begin{array}{l}\text { Types of entrepreneurial } \\
\text { involvement }\end{array}$ & $\begin{array}{l}\text { Number of female } \\
\text { involved }\end{array}$ & Percentage (\%) \\
\hline 1. & Marketing & 67 & $41.87 \%$ \\
\hline 2. & Service & 28 & $17.5 \%$ \\
\hline 3. & Agriculture & 45 & $28.13 \%$ \\
\hline 4. & Manufacturing & 20 & $12.5 \%$ \\
\hline & Total & $\mathbf{1 6 0}$ & $\mathbf{1 0 0 \%}$ \\
\hline
\end{tabular}

Source: Survey Data, 2019.

As represented in the above table, four categories of businesses were identified with marketing taking the lead $(41.87 \%)$ followed by agriculture $(28.13 \%)$ and service $(17.5 \%)$ while manufacturing $(12.5 \%)$ being the least engage business among female entrepreneurs in the aforementioned States investigated.

\section{Results and discussions}

Table 2. Distribution and retrieval of questionnaires

\begin{tabular}{|l|l|l|l|l|l|}
\hline S/No & Locations & $\begin{array}{l}\text { Questionnaires } \\
\text { distributed }\end{array}$ & $\begin{array}{l}\text { Questionnaires } \\
\text { retrieved }\end{array}$ & $\begin{array}{l}\text { Questionnaires } \\
\text { voided }\end{array}$ & Useable \\
\hline 1. & Bayelsa & 40 & 40 & 3 & 37 \\
\hline 2. & Rivers & 40 & 40 & 5 & 35 \\
\hline 3. & Edo & 40 & 40 & 2 & 38 \\
\hline 4. & Delta & 40 & 40 & 2 & 38 \\
\hline & Total & $\mathbf{1 6 0}$ & $\mathbf{1 6 0}$ & $\mathbf{1 2}$ & $\mathbf{1 4 8}(\mathbf{9 3 \%})$ \\
\hline
\end{tabular}

Source: Research data, 2019.

The data collected from the four States were cleans and used for the analysis. Out of the one hundred and sixty (160) copies of the questionnaires distributed across female entrepreneurs in the aforementioned States, one hundred and forty eighty (148) representing 93\% of the study participants were used for the analysis.

Table 3. Entrepreneurs Demographics

\begin{tabular}{|l|l|l|l|}
\hline $\begin{array}{l}\text { Entrepreneurs } \\
\text { Demographics }\end{array}$ & Descriptive items & Frequency & Percentage \\
\hline Age & $18-25$ Years & 27 & $18.2 \%$ \\
\hline
\end{tabular}

2020 | International Journal of Financial, Accounting, and Management/ Vol 2 No 1, 13-27 


\begin{tabular}{|c|c|c|c|}
\hline & 26-35 Years & 35 & $23.6 \%$ \\
\hline & 36 Years/above & 86 & $58.1 \%$ \\
\hline & Total & 148 & $100 \%$ \\
\hline \multirow[t]{5}{*}{ Marital Status } & Single & 18 & $12.2 \%$ \\
\hline & Married & 53 & $35.8 \%$ \\
\hline & Divorced & 31 & $20.9 \%$ \\
\hline & Widows & 46 & $31.1 \%$ \\
\hline & Total & 148 & $100 \%$ \\
\hline \multirow[t]{4}{*}{ Educational attainment } & Primary & 32 & $21.6 \%$ \\
\hline & Secondary & 68 & $45.9 \%$ \\
\hline & Tertiary & 48 & $32.4 \%$ \\
\hline & Total & 148 & $100 \%$ \\
\hline
\end{tabular}

Source: Research data, 2019.

The data on table 3, presents entrepreneurs demographics with three variables to include age, marital status and education respectively. Data on respondents age revealed that $27(18.2 \%)$ falls within $18-25$ years, $35(23.6 \%)$ are between $26-35$ years and $86(58.1 \%)$ are within 36 years and above. On marital status, singles had 18(12.2\%) participants, married women 53(35.8\%) and divorced had 31(20.9\%) while widow had 46(31.1\%) respectively. Conversely, Primary education had 32(21.6\%), Secondary $68(45.9 \%)$ and Tertiary had 48(32.4\%) as female educational level of attainment.

\begin{tabular}{|c|c|c|c|}
\hline & $\mathrm{N}$ & Mean & Std. Deviation \\
\hline Wealth and material gains & 148 & 3.68 & 1.167 \\
\hline Risk taking & 148 & 3.57 & 1.229 \\
\hline Innovation & 148 & 3.34 & .930 \\
\hline Performance & 148 & 3.09 & 1.212 \\
\hline Valid N (listwise) & 148 & & \\
\hline
\end{tabular}

The outcome of the descriptive statistics on the dimensions of socio-cultural factors and performance of female entrepreneurs reveals that socio-cultural factors actually influence performance as all indicators on the mean values exceed that of performance as seen above, given as 3.68; 3.57 and 3.34 as against 3.09 respectively. This results proves the fact that entrepreneurs attitude towards wealth and material gains confers a sense of greater responsibility to give back to society which is a function of entrepreneur's desire to achieve greater goals that are essential for survival and attainment of social status.

It was also revealed that attitude towards risks taking is second to wealth and material gains thus attributed to the fact that female entrepreneurs tend to realize their full potentials despite the uncertainties in the business environment as a result of seeking growth opportunity in order to be self independent in an environment dominated by men. Lastly, entrepreneurs attitude towards change and innovation which tend to believe that female entrepreneurs can actually explore the business environment to gain and sustain competitive advantage if only they could adhere to potential future threats by taking proactive approach towards change in their attitude and behaviours when engaging in venture creation. 
Model Summary

\begin{tabular}{|l|r|r|r|r|}
\hline Model & \multicolumn{1}{|c|}{$\mathrm{R}$} & R Square & $\begin{array}{c}\text { Adjusted R } \\
\text { Square }\end{array}$ & $\begin{array}{c}\text { Std. Error of } \\
\text { the Estimate }\end{array}$ \\
\hline 1 & $.925^{\mathrm{a}}$ & .855 & .852 & .466 \\
\hline
\end{tabular}

a. Predictors: (Constant), Innovation, Wealth and material gains,

Risk taking

The multiple dimensions of socio-cultural factors revealed the nature of influence on female entrepreneurial performance $(\mathrm{R}=.925)$ indicating a favourable level of prediction which is $93 \%$.

ANOVA $^{\mathrm{a}}$

\begin{tabular}{|rl|r|r|r|r|r|}
\hline \multicolumn{1}{|l|}{ Model } & \multicolumn{1}{c|}{$\begin{array}{c}\text { Sum of } \\
\text { Squares }\end{array}$} & Df & Mean Square & F & Sig. \\
\hline \multirow{2}{*}{1} & Regression & 184.617 & 3 & 61.539 & 283.657 & $.000^{\mathrm{b}}$ \\
& Residual & 31.241 & 144 & .217 & & \\
& Total & 215.858 & 147 & & & \\
\hline
\end{tabular}

a. Dependent Variable: Performance

b. Predictors: (Constant), Innovation, Wealth/material gains, Risk taking

Coefficients $^{\mathrm{a}}$

\begin{tabular}{|c|c|c|c|c|c|c|c|c|}
\hline \multirow{2}{*}{\multicolumn{2}{|c|}{ Model }} & \multicolumn{2}{|c|}{$\begin{array}{c}\text { Unstandardized } \\
\text { Coefficients }\end{array}$} & \multirow{2}{*}{$\begin{array}{c}\begin{array}{c}\text { Standardized } \\
\text { Coefficients }\end{array} \\
\text { Beta }\end{array}$} & \multirow[t]{2}{*}{$\mathrm{t}$} & \multirow[t]{2}{*}{ Sig. } & \multicolumn{2}{|c|}{$\begin{array}{c}95.0 \% \text { Confidence } \\
\text { Interval for B }\end{array}$} \\
\hline & & B & $\begin{array}{l}\text { Std. } \\
\text { Error }\end{array}$ & & & & $\begin{array}{l}\text { Lower } \\
\text { Bound }\end{array}$ & $\begin{array}{l}\text { Upper } \\
\text { Bound }\end{array}$ \\
\hline \multirow{4}{*}{1} & (Constant) & -.493 & .156 & & -3.169 & .002 & -.801 & -.186 \\
\hline & Wealth/material gains & .426 & .132 & .410 & 3.222 & .002 & .165 & .688 \\
\hline & Risk taking & .350 & 139 & .355 & 2.519 & .013 & .075 & .624 \\
\hline & Innovation & .228 & .119 & .175 & 1.915 & .057 & -.007 & .464 \\
\hline
\end{tabular}

a. Dependent Variable: Performance

The multiple regression predict female entrepreneurial performance via the dimensions of sociocultural factors which indicates that all three constructs actually predict the variance in female entrepreneurial performance at $95 \%$ confidence level given attitude towards wealth and material gains $(\mathrm{t}=3.222)$; risks taking $(\mathrm{t}=2.519)$ and innovation $(\mathrm{t}=1.915)$ respectively. The outcome revealed that socio-cultural dimensions added together statistically predict female entrepreneurial performance in the four Niger Delta States $\mathrm{f}(3,144)=283.657, \mathrm{p}<0.05$ and $\mathrm{R}^{2}=.855$. The coefficient of determination $\left(\mathrm{R}^{2}=.855\right)$ explains that $86 \%$ of female entrepreneurial performance in the aforementioned States can be explained by socio-cultural factors while $(100.86 \%)=14 \%$ of female entrepreneurial performance cannot be accounted for by the dimensions of socio-cultural factors hence, considered error term.

\section{Partial Correlation of push motivation on socio-cultural factors and performance of female} entrepreneurs

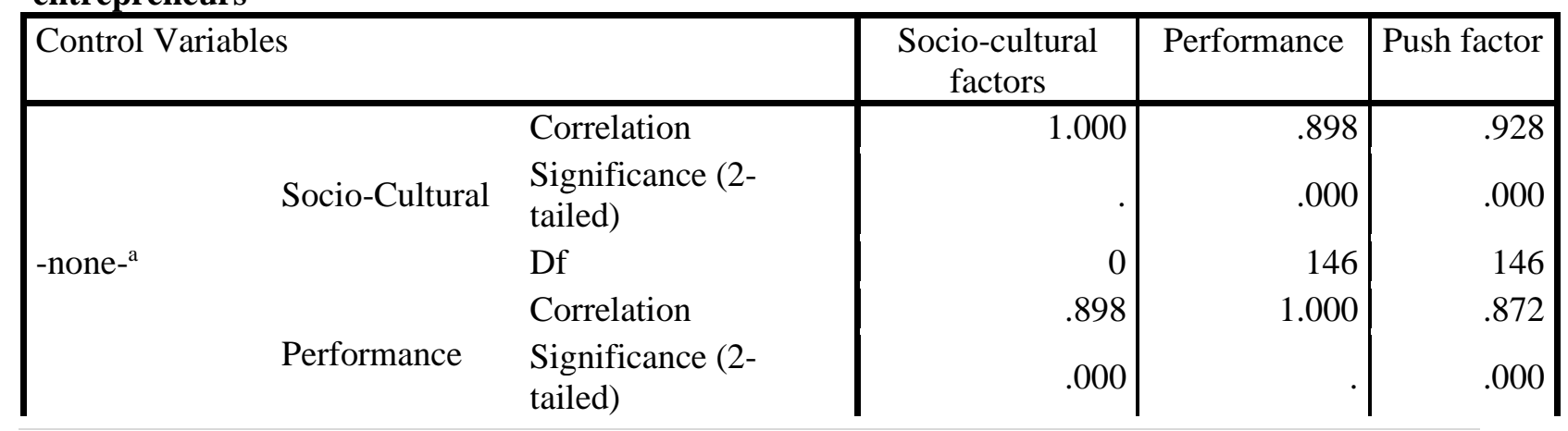

2020 | International Journal of Financial, Accounting, and Management/ Vol 2 No 1, 13-27 


\begin{tabular}{|c|c|c|c|c|c|}
\hline Push Factors & $\begin{array}{l}\text { Push Factors } \\
\text { Socio-Cultural }\end{array}$ & $\begin{array}{l}\text { df } \\
\text { Correlation } \\
\text { Significance (2- } \\
\text { tailed) } \\
\text { df } \\
\text { Correlation } \\
\text { Significance (2- } \\
\text { tailed) } \\
\text { df } \\
\text { Correlation } \\
\text { Significance (2- } \\
\text { tailed) } \\
\text { df }\end{array}$ & $\begin{array}{r}146 \\
.928 \\
.000 \\
146 \\
1.000 \\
. \\
0 \\
.487 \\
.000 \\
145\end{array}$ & $\begin{array}{r}0 \\
.872 \\
.000 \\
146 \\
.487 \\
.000 \\
145 \\
1.000 \\
. \\
0\end{array}$ & $\begin{array}{r}146 \\
1.000\end{array}$ \\
\hline
\end{tabular}

a. Cells contain zero-order (Pearson) correlations.

The result of the correlation reveals that socio-cultural factors correlate performance at (.898) and push factor at (.928) while performance and push motivation at (.872) all indicating significant level of multivariate interaction between the variables. The moderating influence of push factor in the partial correlation indicates that push motivation influences socio-cultural factors on entrepreneurial performance at significant value of (.487) hence, we find positive influence.

Partial Correlation of pull motivation on socio-cultural factors and performance of female entrepreneurs

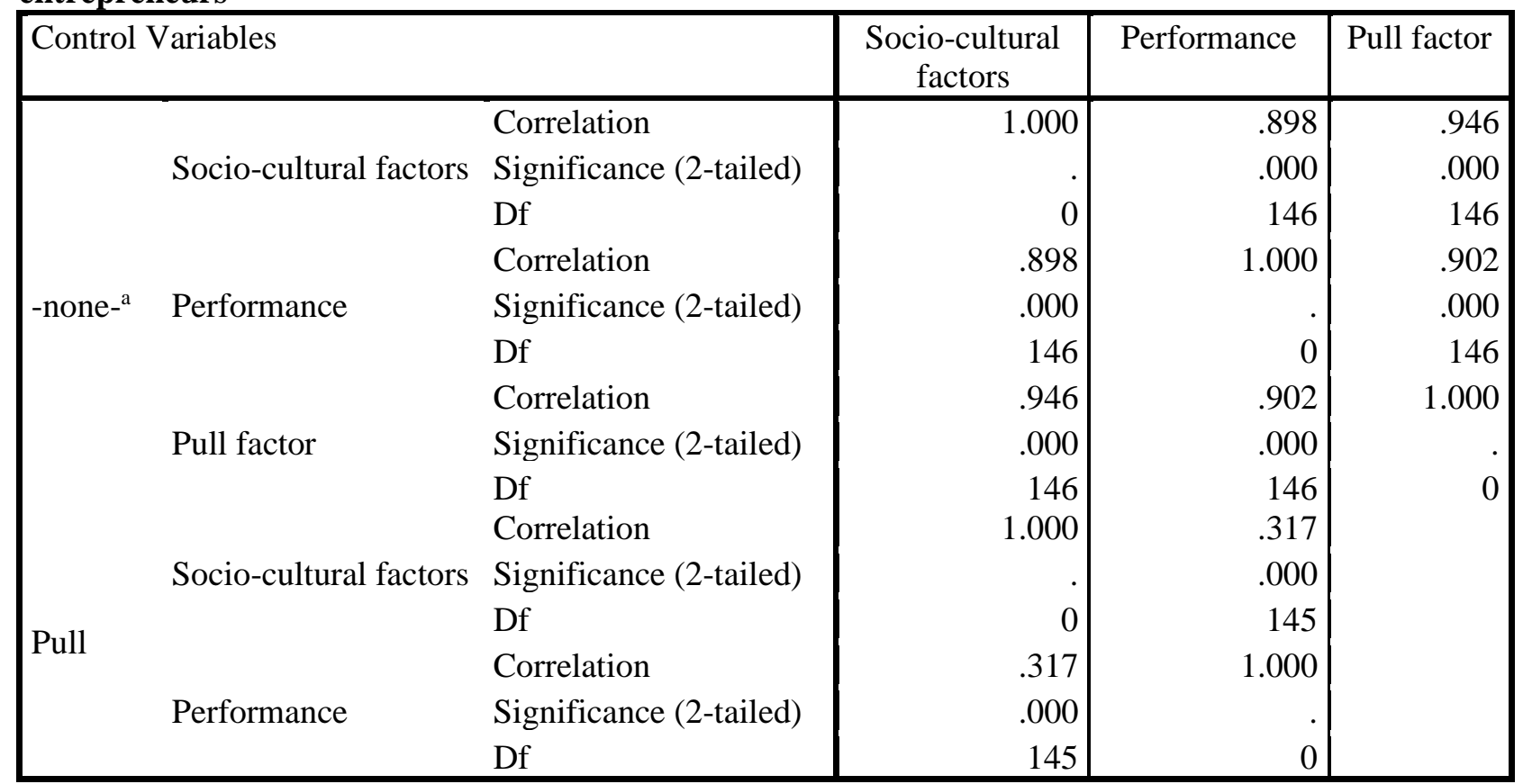

a. Cells contain zero-order (Pearson) correlations.

The correlation between socio-cultural factors and performance has a significant value of (.898) and on pull factor (.946) while performance and push factor, a significant value of (.902) respectively. Conversely, the partial correlation reveals significant value of (.317) indicating it influence on sociocultural factors and entrepreneurial performance. The outcome of these results indicates that pull motivations significantly moderates the influence of socio-cultural factors on female entrepreneurial performance in the aforementioned States. 


\section{Discussion of findings}

The study revealed that attitude towards wealth and material gains confers a sense of responsibility among entrepreneurs which is a function of their desires to achieve greater goals that are essential for survival and the attainment of social status. In consonant with this outcome, Uhlander and Thurik (2007) argued that material gains which are less valuable to post materialist entrepreneurs are determining factors to commercial entrepreneurs; hence, attitude towards wealth and material gains creates desires for achievement which instigate individuals to pursue accomplishment. On the contrary, Urbano, et al., (2014) believes that post materialism is expected to instigate social entrepreneurship among women as they are mostly driven by social projects. Despite these views, it is clear that individuals cannot pursue social entrepreneurship (gaining social status) without the intent of achieving something of value. These values can either be of social recognition or wealth creation towards the attainment of personal goals especially in an uncivilized environment where women are not given full freedom of their own to operate without interference due to cultural barriers.

Risk taking is vital for survival of any venture and as such women need to develop positive attitude towards it in order to survive the turbulence in their entrepreneurial quest amidst socio-cultural challenges in developing settings. Ahn (2010) argued that relative risk tolerance has positive effect on the probability of entering self management. The implication on his position is that entrepreneurs' ability to tolerate moderate risks creates an ability or strength to exploit identified opportunity for the creation of wealth. Therefore, female entrepreneurs in this cultural context need to tolerate moderate level of risks taking propensity when venturing into business; this makes it easier for them to explore the environment since entrepreneurship differs from other business entrant due to individual's astute behaviour towards acting on opportunity despite uncertain conditions and risk involvement.

The study also found out that attitude towards change and innovation can actually spur female entrepreneurial behaviour towards the exploitation of the business environment in order to gain and sustain competitive advantage by taking proactive steps when engaging into new business ventures. In corroboration with this outcome, Priya (2006) believes that innovation being the primary motive behind entrepreneurial intention has positive effect on venture performance. As a reflection of firms tendency to engage and support new ideas and the creation of new product and services that takes organization to new paradigm, innovation instigate entrepreneurs to innovate, change and position their businesses for better performance and as such they need to keep pace with changes in their localities despite socio-cultural influences beleaguering them on daily basis.

The moderating influence of push and pull motivations on socio-cultural factors and female entrepreneurial performance cannot be neglected as each factor has it degree of influence on entrepreneurial level of engagement in the environment where this study was conducted. The push motivation revealed in the outcome of the partial correlation that it significantly moderates the influence of socio-cultural factors on female entrepreneurial performance. The result in line with Muriungi (2012) believes that rural women appears not to be driven by profit but rather necessity to meet up family obligations as a result swing into entrepreneurial engagement in order to liberate themselves from the shackles of begging from their partners in order to survive. This position is not surprising as most men in these cultural contexts still live in the past therefore, tend to bring in obsolete ideas in contemporary era thereby infusing negative attitude towards female entrepreneurial development and or business venturing. This negative assertion towards female entrepreneurial engagement can be overcome(d), if men can embrace current trend in global best practices towards entrepreneurial engagement.

Conversely, the pull motivations as seen in the partial correlation outcome also influence sociocultural factors on female entrepreneurial performance. In support of this position Ingrid, et al., (2010) believes that pull factors forms the basis for opportunity entrepreneurs to start-up new venture thereby reducing unemployment as well creating jobs that would boost the economy. Pull entrepreneurs are seen to be more resilience and successful in terms of venture creation which enhances personal and economic development. This category of entrepreneurs becomes successful in their entrepreneurial activities such that they grow above cultural barriers as seen in the case of necessity entrepreneurs that are hindered mostly by surrounding cultural activities.

2020 | International Journal of Financial, Accounting, and Management/ Vol 2 No 1, 13-27 
Finally, the regression analysis revealed that socio-cultural factors predict female entrepreneurial performance among the four Niger Delta States. This result is not surprising as cultural related activities do not have respect for female entrepreneurial engagement rather relinquish women to domestic activities. Mbiti, et al., (2015) noted that women household roles affect their access to entrepreneurial training and as such receives limited support from family authority which greatly influences their business performances. However, women in this cultural environment need to play second fiddle in their quest to overcome some of these cultural excesses and in achieving this fit, they must embrace education which would equip them with requisite knowledge to challenge some of the cultural activities that impinges on their right. Furthermore, Mbiti, et al., op cit contend that society has conditioned women to believe that men's opinion are more credible such that women are made to believe in men's decision since they are better informed and socially connected. Nevertheless, these cultural excesses need to be curtailed as most men still live in their past with the mentality imposed by societal norms therefore, women need to embrace contemporary doings from their counterparts in the western world in order to survive in their entrepreneurial behaviours.

\section{Conclusion}

Considering the significant roles women play towards eradicating poverty and unemployment among societies via entrepreneurial involvement, the fact still remains as to what actually hinders their performance since they operate in an environment dominated by cultural activities with huge profit and growth potentials hence, the tendencies to flourish becomes inevitable amidst these influences. However, the influence of cultural practices instigates the burning desires for self recognition and social mobility which has necessitated entrepreneurs' behaviour towards venture creation for the sake of survival or wealth creation via opportunity identification. Culture as a people way of life shapes individual behaviour as well as influences attitudes towards entrepreneurial venturing either as a means of necessity or drivers of opportunity or the combination of both. Drivers of necessity due to lack of employment option and the need for self sustenance and survival and drivers of opportunity geared towards wealth creation as a result of opportunity identification capitalized to gain and sustain competitive advantage.

The overall findings of the study proves the fact that female entrepreneurial performance among Niger Delta States is predicted by socio-cultural influences which by implication holds the very fact that women only have their place in domestic activities. However, female entrepreneurs can only succeed in their entrepreneurial quest by embracing education that will equip them with the requisite knowledge to challenge some cultural excesses in the region as most men tend to live in the past thereby bringing obsolete ideas in contemporary era which infuses negative attitudes towards female entrepreneurship.

Despite this ugly scenario, female entrepreneurs in the aforementioned States need to embrace change in their attitudes towards wealth and material gains, attitudes towards change/innovation and attitude towards risks taking propensity as these are some of the factors that can spur entrepreneurial behaviour towards greater performance. Nevertheless, it is an established fact that intention predicts behaviour therefore, female entrepreneurs in this cultural niche need to take personal initiative to furnish the kind of behaviour typically associated with an entrepreneurial mindset if they must survive discrimination from cultural practices by building network across borders. In corroboration with the above assertion, Yadav and Unni (2016) argued that young women need to explore entrepreneurial intention in order to foster entrepreneurship development amidst varied socioeconomic and class backgrounds in different cultural context, since human action is often guided by certain considerations. This, aspiring female entrepreneurs stand to gain through apprenticeship in target industries which stand to support in preparing them prior to lunching their own business venture(s). Based on these, the study advocated for a clarion call on government to checkmate some of the cultural excesses in order to encourage female entrepreneurial participation considering their role towards poverty reduction in the region. The study also discourages the necessity entrepreneurs need to turn their disadvantage situations into opportunity seekers as this will enable them contribute positively to societal development amidst socio-cultural challenges. 


\section{Limitation and study forward}

Since it is not feasible to cover all aspect of a giving study, the researchers wish to register their profound limitation in their inability to cover all the nine Niger Delta States due to financial constraints. We wish to advocate for further research covering all the States while taking into cognizance the behavioural implication of cultural practices on entrepreneurial engagement in the given environment.

\section{Acknowledgement}

The authors wish to acknowledge Dr. B. M. Nwibere and Dr. A. Christopher who initiated this field of thinking to the researchers that carried out this study as we thank our institution (Niger Delta University) for giving us the platform to exploring our knowledge in entrepreneurship studies.

\section{References}

Adim, C. V., Tamunomiebi, M. D., Akintokunbo, O. O., \& Adubasim, I. E. (2018).

Entrepreneurial innovativeness and performance of women entrepreneurs in Rivers State, Nigeria. World Journal of Entrepreneurial Development Studies, 2(1), 9-23.

Ahn, T. (2010). Attitude towards risk and self employment of young workers. Labour Economics, 17(2), 434-442.

Aldrich, H. E., \& Zimmer, C. (1986). Entrepreneurship through social networks. In Sexton, D., $\&$ Smilar, R. (eds) The Art and Science of Entrepreneurship. New York; Ballinger, 3-23.

Anikpo, M. O. C., \& Atemie, J. D. (2006). Nigerian socio-cultural heritage. Peekay Production, Port-Harcourt.

Ashley, V. W., Nathan, J. W., \& Dunn, W. E. (2016). Seeing wealth as a responsibility improves attitudes towards taxation. Journal of Economic Behaviour and Organization, 127: 146-154.

Cocioc, P. (2017). On the attitude to risk and the decision making behaviour. Review of economic Studies and Research Vigil Madgearu, 10(1), 27-46.

Eniola, A. A., \& Dada, D. A. (2018). The performance of women entrepreneurs: Human and financial capital. Triple A Research Journal of Social Science and Humanity, 2(1), 30-37.

Gilad, B., \& Levine, P. (1986). A behavioral model of entrepreneurial supply. Journal of Small Business and Management, 24(4), 45-53.

Hartog, C., \& Hoogendoorn, B. (2011). Prevalence and determinants of social entrepreneurship at the macro-level. H201022, EIM Business and Policy Research.

Ingrid, V., Roy, T., Jolanda, H., \& Peter, V. Z. ( 2010). Factors influencing the entrepreneurial engagement of opportunity and necessity entrepreneurs. EIM Business and Policy Research, 3-22.

Kabote, J. S. (2018). Influence of women entrepreneurs characteristics on personal wellbeing in Arumeru district in Tanzania. African Journal of Business Management, 12(11), 316-328.

Khare, A. (2014). Money attitudes, materialism, and compulsiveness: Scale development and validation. Journal of Global Marketing, 27(1), 30-45.

Korosec, R. L., \& Berman, E. M. (2006). Municipal support for social entrepreneurship. Public Administration Review, 66(3), 448-462.

Lebedeva, N. M., and A. N. Tatarko. (2009).Strategii Mezhkul'turnogo vzaimodejstvija migrantov i naselenija Rossii [Strategies of intercultural interaction of migrants and sedentary population in Russia]." Moscow, Russia: RUDN.

Mauchi, N. F., Mutengezanwa, M., \& Damiyano, D. (2014). Challenges faced by women entrepreneurs: A case study of Mashoraland central province. International Journal of Development and Sustainability, 3(3), 466-480.

Mbiti, M. F., Mukulu, E., Mung'atu J., \& Kyalo, D. (2015). The influence of socio-cultural factors on growth of women owned micro and small enterprises in Kitui County, Kenya. International Journal of Business and Social Science, 6(7), 242-250.

Mufaro, A. M., Lucky, T. M., \& Noel, Z. (2018). Women entrepreneurs in Botswana: Economic and socio-cultural issues and challenges. Researchjournali's Journal of Entrepreneurship, 6(4), 1-13.

Muriungi, F. M. (2012). The challenges facing small scale women entrepreneurs. Case of Kenya. International Journal of Business Administration, 3(2), 112-114. 
National Foundation for Women Business Owners. (2000). Survey Finds Business Owners are Philanthropic Leaders. National Foundation for Women Business Owners, Washington, DC.

Nwibere, B. M., Emecheta, B. C., \& Worlu, G. O. (2011). Comparative Management: A System Approach. Samac Stationery Limited, Port-Harcourt.

Oshi, J. E. O., Ule, P. A., \& Ogah, J. I. (2017). Entrepreneurial intensity and corporate sustainability in the Nigerian extractive industry. Account and Financial Management Journal, 2(12), 1218-1225.

Priya, S. (2006). Policy and innovative financing advisor at center for accelerate innovation and impact at USAID. Washington, DC; World Bank.

Rahma, A., \& Farhana, R. S. (2014). Socio-cultural factors influencing entrepreneurial activities: A study on Bangladesh. IOSR Journal of Business and Management, 16(9), 01-10.

Ramdani, Z., Marliani, R., \& Rahman, A. A. (2019). The individual work performance scale: A psychometric study and its application for employee performance. Humanities \& Social Sciences Reviews, 7(5), 405-414.

Sari, P. K., William, R. K., \& Xu, T. (2017). Personality traits of entrepreneurs: A review of recent literature. Wellesley College Working Paper, page 18-47.

Shane, S. (1993). Cultural influences on national rates of innovation. Journal of Business Venturing, 8: 59-73.

Shane, S., \& Venkataraman, S. (2000). The promise of entrepreneurship as a field of research. Academy of Management Review, 25(1), 217-226.

Shapero, A., \& Sokol, L. (1982). The social dimensions of entrepreneurship, in Kent, C., Sexton, D., and Vesper, K. (eds), The Encyclopedia of Entrepreneurship. Englewood Cliffs, NJ: Prentice-Hill, 72-90.

Singh, A., \& Manish, R. (2013). Women entrepreneurs in micro small and medium entgerprises. International Journal of Management and Social Science Research, 2(8).

Spevacek, A. M. (2010). Constraints to female entrepreneurship in Sub-Saharan Africa. KSC Research Series, retrieved from http://pdf.usaid.gov//pdf_docs/pnadm070.pdf

Srivastava, A., Locke, E. A., \& Bartol, K. M. (2001). Money and subjective wellbeing: It's not the money, it's the motive. Journal of Personal Social Psychology, 80(6), 959.

Tuyishime, C., Jaya, S., \& Gaurav, B. (2015). The challenges faced by women entrepreneurs in business expansion: A case study of women members of handicraft co-operatives in Nyarugenge district. Kigali Africalics Second International Conference, University of Rwanda.

Uhlander, L., \& Thurik, R. (2007). Post-materialism influencing total entrepreneurial activity across nations. Journal of Evolutionary Economics, 17, 161-185.

Ule, P. A. (2012). The influence of socio-cultural factors on the performance of female entrepreneurs: A study of selected small and medium scale enterprises in Bayelsa State. Project submitted to the Department of Management, Faculty of Management Sciences, University of Port-Harcourt.

Urbano, P. D., Ferri, J. E., \& Noguera, N. M. (2014). Female social entrepreneurship and socialcultural context: An international analysis. Revista de Estudios Empresariales, 2, 26-40.

Van Ryzin, G., Grossman, S., Dipadova-Stocks, L., \& Bergrud, E. (2009). Portrait of the social entrepreneur: Statistical evidence from a US panel. Voluntas, 20, 129-140.

Wilson, F., Kickul, J., \& Marlino, D. (2007). Gender entrepreneurial self efficacy and entrepreneurial career intentions: Implications for entrepreneurship education. Entrepreneurship Theories and Practice, 31(3), 387-406.

Yadav, V., \& Unni, J. (2016). Women entrepreneurship: Research and future directions. Journal of Global Entrepreneurship Research, 6(12), 2-18. 


\section{Appendix \\ Questionnaire on the influence of socio-cultural factors on the performance of female entrepreneurs}

1. Business location and State of operation:

2. Type of business activity. (a) Marketing

(b) Servicing

(c) Agriculture

(d) Manufacturing

$\square$

3. Respondent age bracket.

(a) $18-25$

(b) $26-35$

(c) 36 and above

4. Marital status:

(a) Single

(b) Married

(c) Divorced

(d)

Widow

5. Academic qualification. (a) Primary

(b) Secondary

(c) Tertiary

Part B: Socio-cultural Factors Dimensions

\begin{tabular}{|c|c|c|c|c|c|c|}
\hline $\mathbf{B i}$ & Attitude towards wealth/material gains & $\begin{array}{l}\mathbf{S A} \\
\mathbf{5}\end{array}$ & $\begin{array}{l}\mathbf{A} \\
4\end{array}$ & $\begin{array}{l}\text { MA } \\
\mathbf{3}\end{array}$ & $\begin{array}{l}\text { D } \\
2\end{array}$ & $\begin{array}{l}\text { SD } \\
1\end{array}$ \\
\hline 1. & My life would be better, if I own certain things I don't have. & & & & & \\
\hline 2. & I'd be happier if I could afford to buy more things for myself. & & & & & \\
\hline 3. & I use money to influence other people to do things for me. & & & & & \\
\hline 4. & $\begin{array}{l}\text { I admire people who own expensive homes, cars and other } \\
\text { luxuries. }\end{array}$ & & & & & \\
\hline 5. & I'd like to own things that impress people. & & & & & \\
\hline 6. & The things I own speaks lot of how well I am doing in life. & & & & & \\
\hline 7. & Money is the ultimate symbol of success for me. & & & & & \\
\hline 8. & $\begin{array}{l}\text { Material possessions are some of the important achievement in } \\
\text { life. }\end{array}$ & & & & & \\
\hline 9. & $\begin{array}{l}\text { I often show signs of nervous when I don't have enough } \\
\text { money. }\end{array}$ & & & & & \\
\hline 10. & I hesitate to spend money even on necessities. & & & & & \\
\hline Bii & Attitude towards change/ innovation & & & & & \\
\hline 11. & I often surprise people with my innovative ideas. & & & & & \\
\hline 12. & I like situations in which I compete with others. & & & & & \\
\hline 13. & I am an inventive person with good ideas about business. & & & & & \\
\hline 14. & I hate changing from what I know. & & & & & \\
\hline 15. & $\begin{array}{l}\text { I gain more satisfaction from mastering a skill than coming up } \\
\text { with a new idea. }\end{array}$ & & & & & \\
\hline 16. & $\begin{array}{l}\text { People often ask me for help when it comes to creative } \\
\text { activities. }\end{array}$ & & & & & \\
\hline 17. & I am not a very creative person. & & & & & \\
\hline 18. & $\begin{array}{l}\text { I like a business that demands skill and practice than } \\
\text { inventiveness. }\end{array}$ & & & & & \\
\hline 19. & $\begin{array}{l}\text { I am able to create added value from my personal observation } \\
\text { of the environment. }\end{array}$ & & & & & \\
\hline
\end{tabular}




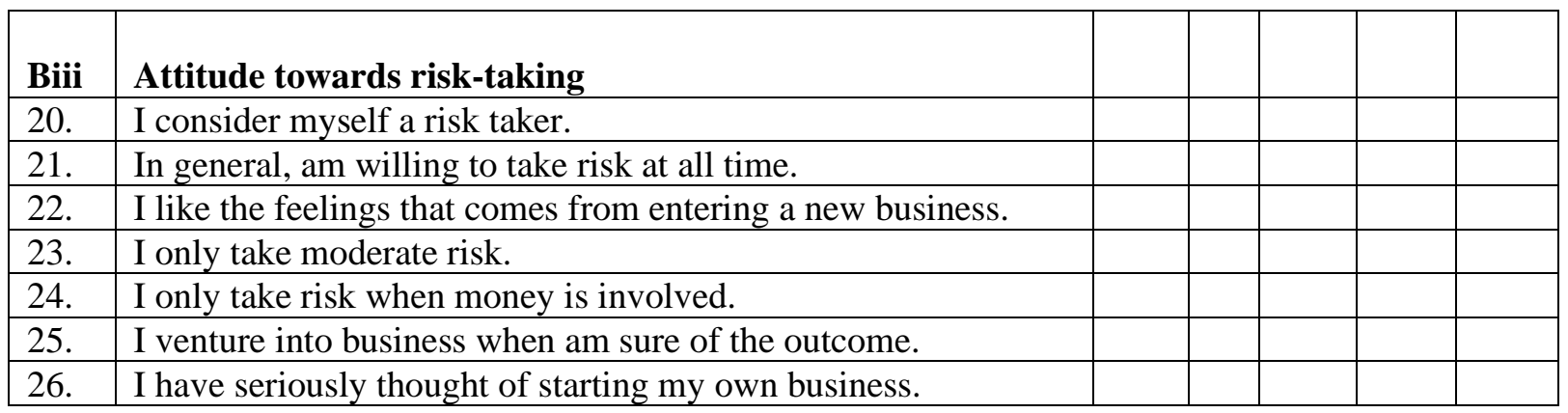

\section{Part C: Performance of female entrepreneurs}

\begin{tabular}{|c|c|c|c|c|c|c|}
\hline & Performance & $\begin{array}{l}\text { SA } \\
5\end{array}$ & $\begin{array}{l}\mathbf{A} \\
\mathbf{4}\end{array}$ & $\begin{array}{l}\text { MA } \\
\mathbf{3}\end{array}$ & $\begin{array}{l}\text { D } \\
2\end{array}$ & $\begin{array}{l}\text { SD } \\
1 \\
\end{array}$ \\
\hline 27. & I often fulfill my responsibility daily. & & & & & \\
\hline 28. & My interaction with others led to my desired result. & & & & & \\
\hline 29. & I take initiative when there is problem to be solved. & & & & & \\
\hline 30. & $\begin{array}{l}\text { I try to learn from the feedback I got from other business } \\
\text { women ahead of me. }\end{array}$ & & & & & \\
\hline 31. & I often recover fast, after difficult situations and setback. & & & & & \\
\hline 32. & I always come up with creative ideas at my business place. & & & & & \\
\hline 33. & I easily adjust to change when the need arises. & & & & & \\
\hline $\mathbf{D}$ & Propellant of entrepreneurship & & & & & \\
\hline Di & Push motivations & & & & & \\
\hline 34. & I became an entrepreneur because of unemployment. & & & & & \\
\hline 35. & I am into business because of family hardship. & & & & & \\
\hline 36. & $\begin{array}{l}\text { My lack of higher formal education instigates my desire to be } \\
\text { in business. }\end{array}$ & & & & & \\
\hline 37. & I do business to avoid responsibility. & & & & & \\
\hline 38. & I was never happy with my previous job. & & & & & \\
\hline 39. & I am into business because I needed to survive. & & & & & \\
\hline 40. & I need to plan for my children future. & & & & & \\
\hline Dii & Pull motivations & & & & & \\
\hline 41. & $\begin{array}{l}\text { I identified an opportunity to be wealthy that's why am into } \\
\text { business. }\end{array}$ & & & & & \\
\hline 42. & I want social recognition. & & & & & \\
\hline 43. & Business runs in my family blood. & & & & & \\
\hline 44. & $\begin{array}{l}\text { My desire to earn extra money for my family gives rise to my } \\
\text { business quest. }\end{array}$ & & & & & \\
\hline 45. & $\begin{array}{l}\text { I became a business woman because of my desire to command } \\
\text { authority in my locality. }\end{array}$ & & & & & \\
\hline 46. & $\begin{array}{l}\text { I love challenges when it comes to what I know in terms of } \\
\text { business. }\end{array}$ & & & & & \\
\hline 47. & I'd rather work for myself than others. & & & & & \\
\hline 48. & I inherited this business from my immediate family. & & & & & \\
\hline
\end{tabular}

KEY: SA = Strongly Agree

$$
\text { A }=\text { Agree }
$$

MA = Moderately Agree

$\mathbf{D}=$ Disagree

SA $=$ Strongly Disagree 